\title{
Origin of Zircon from a Lherzolite Lens Based on its U-Pb SHRIMP Age, Lu-Hf Isotopic System and Trace Elements: An Input to Revealing of 2.8Ga Magmatism in the Paleoarchean Bug Granulite Complex (The Ukrainian Shield)
}

Lobach-Zhuchenko SB ${ }^{1}$, Sergeev SA ${ }^{2,3}$, Baltybaev Sh.K ${ }^{1 *}$, Lokhov KII,3, Egorova Ju.S1, Galankina OL ${ }^{1}$, Balagansky VV ${ }^{4}$, Skublov $\mathrm{SG}^{1,5}$, Bogomolov ES ${ }^{1,3}$ and Berezhnaya $\mathrm{NG}^{3}$

${ }^{1}$ Institute of Precambrian Geology and Geochronology, Russia

${ }^{2}$ Saint Petersburg State University, Russia

${ }^{3}$ Karpinsky Russian Geological Research Institute, Russia

${ }^{4}$ Geological Institute of the Kola Science Centre, Russia

${ }^{5}$ Saint-Petersburg Mining University, Russia

*Corresponding author: Baltybaev Sh.K, Institute of Precambrian Geology and Geochronology, Russian Academy of Sciences, Saint Petersburg, Russia

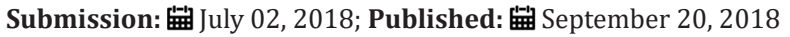

\begin{abstract}
The Bug granulite complex (BGC) comprises mainly Paleoarchean orthogneisses and represents the oldest portion of the Ukrainian shield. It has a very long (3.8-2.0Ga) and a complex evolutionary history and contains numerous mafic and ultramafic enclaves of different age and origin. This study is focused on a zoned peridotite lens within the orthogneisses. Zircon separated from a marginal websterite part of the lens yielded a U-Pb (SIMS SHRIMP II) age of 2814 $\pm 51 \mathrm{Ma}$. In-situ U-Pb and Lu-Hf isotopic analyses combined with BSE and CL imaging and trace element data provided evidence of magmatic origin of zircon. The $\varepsilon \mathrm{Hf}$ (2.8Ga) of zircon varies from -8.5 to -10.7 and indicates that the ultramafic melt contained an old component probably assimilated from the host orthogneiss. Field observations and obtained analytical data suggest that the lens is a fragment of a lherzolite dyke, and the age $2.81 \mathrm{Ga}$ is interpreted as the age of its crystallization.
\end{abstract}

Keywords: Zircon; SHRIMP II; Archean; Peridotite; Ukrainian shield

\section{Introduction}

The BGC is located in the southwestern Dniester-Bug Province of the Ukrainian shield (Figure $1 \mathrm{~A}$ ) and consists of felsic orthogneiss with minor mafic-ultramafic enclaves. The BGC units show imprints of several geological events: 3.7-3.66, 2.8, 2.3 and 2.0Ga [1-3]. Age of $3.3 \mathrm{Ga}$ has been recently obtained for magmatic zircon from the orthopyroxenite enclave (zircon, U-Pb SHRIMP, [3]). The broad peak around $2.8 \mathrm{Ga}$ on the histogram of $\mathrm{U}-\mathrm{Pb}$ zircon ages reflects the age of high-temperature metamorphic event [1,2]. But simultaneous igneous mafic-ultramafic rocks were not found within studied area. So, the purpose of our study is to fill this gap of magmatic activity.

\section{Geological Setting}

The BGC (Figure 1A) consists of foliated and migmatized enderbites (now orthogneisses) with enclaves of mafic rocks and layers of met sediments [2,4]. The study area (Figure 1B) is a typical example of all these rocks. In addition, a few ultramafic enclaves occur in the area. Orthogneiss is 3.8-3.6Ga old [3,5-8]. Geological record in all these rocks demonstrates their complicate tectonic evolution. The deformation D1 led to a N-S-striking or NW-SEstriking steep foliation and sometimes was accompanied by weak migmatization. The next deformations (D2 and D3) resulted in W-E to WNW-ESE trending steep shear zones and foliations of the same orientation.

Enclave UR17/2 is a small lens-like body of a lherzolite mantled by a websterite, occurring in the orthogneiss (Figure 1C). The upper (in the picture) pinching part of the lens (17/2-4, Figure 1C) is represented by a pargasite-plagioclase orthopyroxenite. This lens and orientations of its structural elements (Figure 1B) formed 
during the second deformation when the W-E to WNW-ESE striking shear zone and steep lineation developed. The lherzolite consists mainly of olivine, orthopyroxene, clinopyroxene, phlogopite, minor serpentine, carbonate and accessory chrom spinel, pentlandite, apatite, magnetite. A mineral assemblage of websterite is the same beside the absence of olivine and the higher abundance of phlogopite (Table 1). While the lherzolite has usual mineral

Table 1: Major element composition of minerals from lherzolite, websterite and inclusions in zircon from a peridotite lens UR17/2.

\begin{tabular}{|c|c|c|c|c|c|c|c|c|c|c|c|}
\hline Rock/Mineral & $\mathbf{n}$ & $\mathrm{SiO}_{2}$ & $\mathrm{TiO}_{2}$ & $\mathrm{Al}_{2} \mathrm{O}_{3}$ & $\mathrm{Cr}_{2} \mathrm{O}_{3}$ & $\mathrm{FeO}$ & Mno & MgO & $\mathrm{CaO}$ & $\mathrm{Na}_{2} \mathrm{O}$ & $\mathbf{K}_{2} \mathbf{O}$ \\
\hline \multicolumn{12}{|c|}{ Liherzolite } \\
\hline Ol & 47 & 40.003 & nd & 0.07 & nd & 13.66 & nd & 45.77 & nd & nd & nd \\
\hline Opx & 41 & 56.6 & nd & 0.92 & 0.05 & 9.51 & 0.18 & 32.47 & 0.21 & nd & nd \\
\hline Cpx & 17 & 54.41 & 0.24 & 0.58 & 0.32 & 2.62 & 0.18 & 17.5 & 24.85 & nd & nd \\
\hline $\mathrm{Phl}$ & 34 & 40.58 & 1.61 & 14.25 & 0.52 & 3.27 & 0.02 & 24.68 & nd & 0.26 & 10.59 \\
\hline Serp & 4 & 42.68 & nd & 0.14 & nd & 2.3 & nd & 41.53 & nd & nd & nd \\
\hline $\mathrm{Sp}$ & 16 & 0.11 & 1.56 & 16.57 & 27.19 & 44.54 & 0.06 & 4.44 & 0.03 & nd & nd \\
\hline \multicolumn{12}{|c|}{ Websterite } \\
\hline Opx & 51 & 55.5 & 0.08 & 1.25 & 0.03 & 12.905 & 0.28 & 29.605 & 0.32 & nd & nd \\
\hline Cpx & 11 & 53.78 & 0.08 & 1.48 & 0.18 & 3.88 & 0.13 & 16.62 & 24.6 & 0.3 & nd \\
\hline $\mathrm{Phl}$ & 39 & 40.32 & 1.51 & 14.48 & 0.28 & 4.97 & 0.02 & 23.58 & nd & 0.23 & 10.305 \\
\hline Amph & 14 & 47.68 & 0.45 & 9.8 & 0.41 & 5.23 & 0.06 & 18.62 & 12.63 & 1.65 & 0.71 \\
\hline \multicolumn{12}{|c|}{ Prg-Pl- orthopyroxenite } \\
\hline Opx & 19 & 52.95 & nd & 1.45 & nd & 23.15 & 0.58 & 21.48 & 0.38 & nd & nd \\
\hline $\mathrm{Pl}$ & 7 & 56.58 & nd & 27.8 & nd & nd & nd & nd & 9.44 & 6.04 & 0.13 \\
\hline Prg & 9 & 43.09 & 1.15 & 12.68 & 0.77 & 12.44 & 0.17 & 12.56 & 11.96 & 1.52 & 1.6 \\
\hline Phl & 5 & 38.28 & 2.29 & 15.33 & 0.38 & 12.35 & 0.07 & 17.1 & nd & nd & 10.26 \\
\hline \multicolumn{12}{|c|}{ Inclusions in Zircon } \\
\hline Opx & s888 & 56.04 & nd & 1.4 & nd & 13.29 & 0.27 & 29 & nd & nd & nd \\
\hline Opx & s17 & 55.49 & nd & 1.47 & nd & 13.52 & 0.4 & 28.8 & 0.3 & nd & nd \\
\hline Opx & s18 & 55.01 & nd & 1.56 & nd & 13.82 & 0.2 & 29.27 & 0.03 & nd & nd \\
\hline Opx & s31 & 55.75 & nd & 1.27 & 13.29 & 0.15 & 29.23 & 0.3 & nd & nd & nd \\
\hline Opx altered & s4 & 63.69 & nd & nd & nd & 11.86 & nd & 23.71 & nd & 5.7 & nd \\
\hline Opx altered & s4 & 62.58 & nd & nd & nd & 10.95 & nd & 25.28 & nd & 0.74 & nd \\
\hline Opx altered & s6 & 52.05 & nd & 0.29 & nd & 11.7 & nd & 16.47 & nd & 0.89 & nd \\
\hline Opx altered & s6 & 50.5 & nd & 0.33 & nd & 9.74 & 0.01 & 16.8 & nd & 0.89 & nd \\
\hline $\mathrm{Phl}$ & s10 & 42.11 & 1.31 & 15.62 & nd & 5.18 & nd & 24.95 & nd & 0.39 & 10.44 \\
\hline Phl & s11 & 41.93 & 1.59 & 16.38 & nd & 6.12 & nd & 22.8 & nd & 0.37 & 10.82 \\
\hline $\mathrm{Phl}$ & s16 & 41.86 & 1.33 & 15.96 & nd & 5.2 & 0.03 & 24.79 & nd & 0.51 & 10.4 \\
\hline $\mathrm{Phl}$ & s4 & 42.31 & 1.58 & 15.55 & nd & 6.35 & 0.22 & 23.17 & nd & 0.54 & 10.71 \\
\hline nd & s5 & 48.69 & 0.03 & 5.37 & nd & 28.96 & 0.65 & 14.35 & 0.72 & 0.55 & 0.68 \\
\hline
\end{tabular}




\begin{tabular}{|c|c|c|c|c|c|c|c|c|c|c|c|}
\hline nd & s6 & 50.51 & 0.01 & 5.69 & nd & 24.53 & 0.56 & 16.18 & 0.62 & 0.47 & 1.43 \\
\hline Pl & s37 & 54.99 & nd & 29.26 & nd & nd & nd & nd & 10.43 & 5.32 & nd \\
\hline Pl & s43 & 54.94 & nd & 28.87 & nd & nd & nd & nd & 10.34 & 5.7 & 0.15 \\
\hline Cpx altered & s60 & 56.76 & nd & 0.61 & nd & 12.98 & 0.85 & 21.14 & 6.68 & 1.1 & 0.06 \\
\hline Amp & s58 & 48.83 & 0.55 & 11.54 & nd & 6.17 & 0.07 & 17.46 & 12.61 & 1.71 & 1.7 \\
\hline Carb & s6 & 4.55 & nd & nd & nd & 7.84 & 1.1 & 34.18 & 59.34 & nd & nd \\
\hline
\end{tabular}

Major and trace element analyses were produced using a JED-2200 (JEOL) microprobe coupled with an SEM JSM-6510LA spectrometer at the Institute of Precambrian Geology and Geochronology, RAS, St.-Petersburg. The microprobe analyses were carried out with

current settings of $20 \mathrm{kV}$ and $1.5 \mathrm{nA}$, and the ZAF-correction method was used.

nd - not detectable, $\mathrm{n}$ - number of analyses, (if it begins with "s" see in Fig. 4).

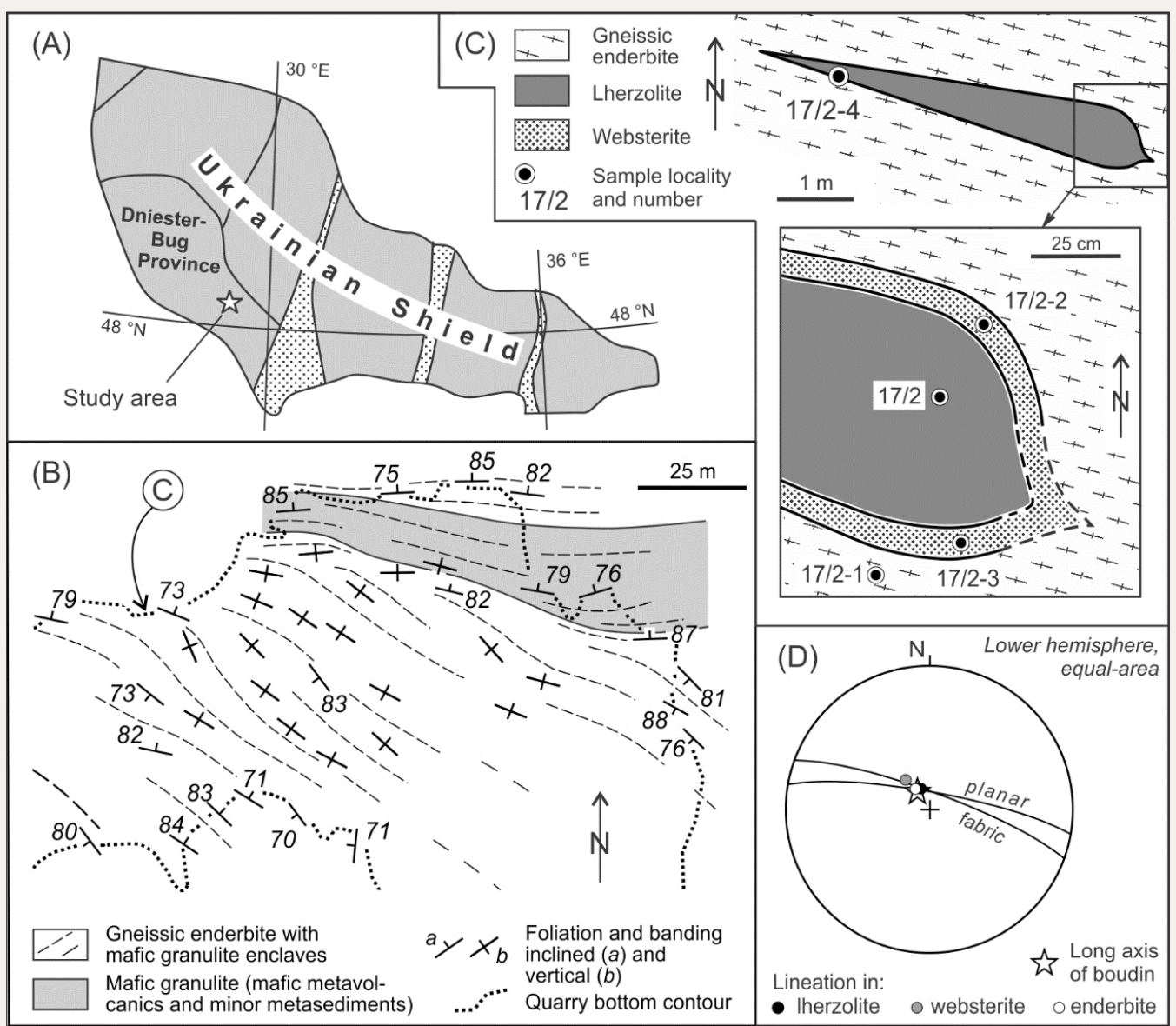

Figure 1A: Location of the Dniester-Bug Province in the tectonic structures of the Ukrainian Shield (grey, tectonic provinces; dotted, transitional zones separating provinces).

Figure 1B: Sketch geological map of the northern part of the Odessky quarry [3].

Figure 1C: Geological sketch of exposure UR-17/2.

Figure 1D: Stereo plot of planar and linear fabrics in exposure UR-17 (software "OpenStereo 0.1.2 devel" by C.H. Grohmann and G.A.C. Campanha).

\section{Morphology and Composition of Zircon}

Zircon was separated from a websterite margin (sample UR 17/2-3; Figure 1C). Zircon population is characterized by the heterogeneous morphology. Using Back-Scattered Electron image (BSE) data we approximately may distinguish three zircon groups (Zircon I, II, III). Zircon I forms rounded grains ca. 200*250 $\mu$ m in size, some grains are faceted (Figure 2). Several small zircon grains hosted in orthopyroxene are interpreted as zircon I. In Cathodo-
Luminescence (CL) images these grains are medium or weak and display a broad zoning. In BSE both small and large grains of zircon I are homogeneous and grey in color.

Zircon II represented by 3 grains, CL images reveal a two-phase internal texture: the dark grains contain CL-bright domains with a complex texture. BSE images show an irregular pattern of grey and light-grey domains corresponding to different $\mathrm{Zr} / \mathrm{Hf}$ ratios (Figure 2). 


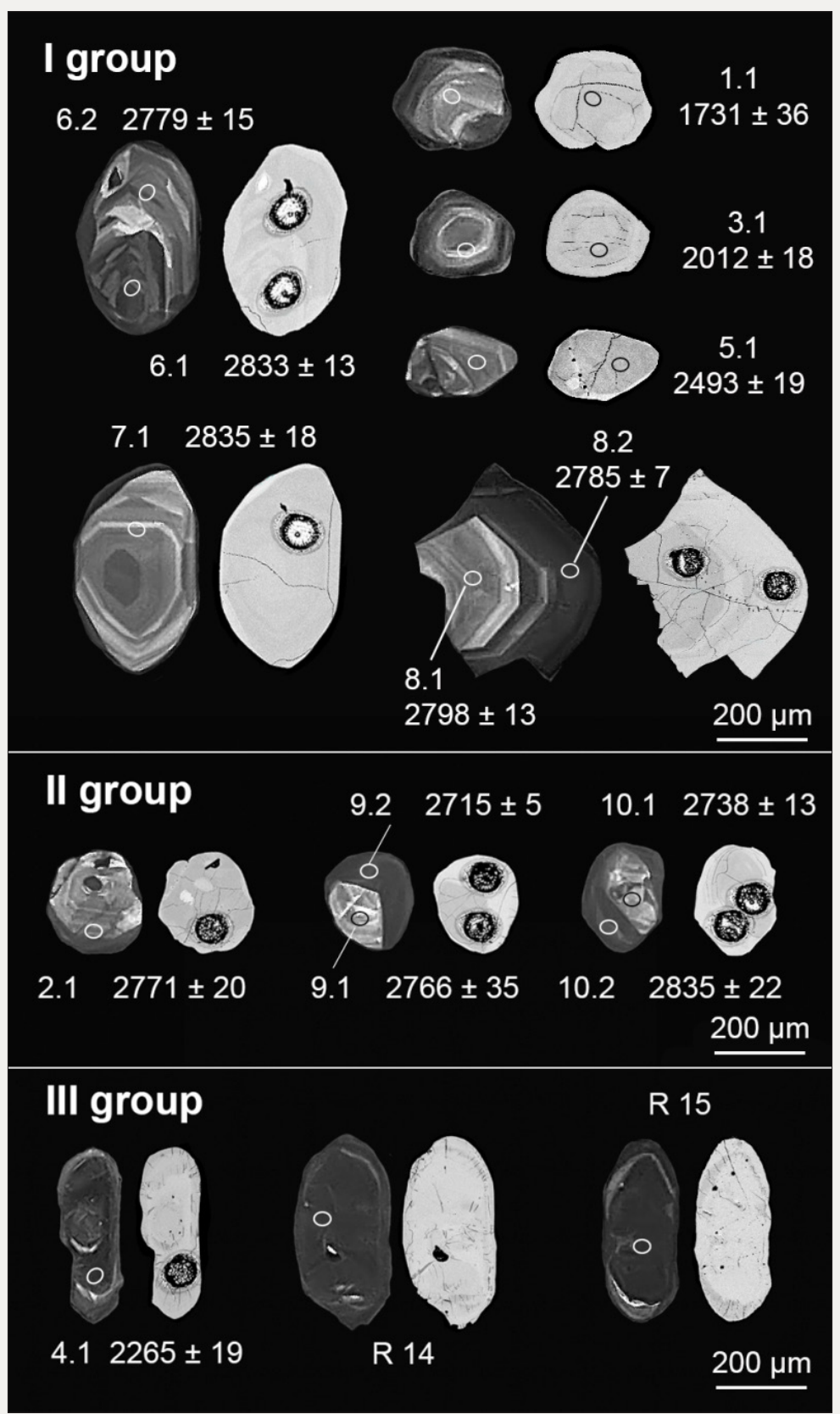

Figure 2: Cathodoluminescence and back-scattered electron images of selective zircons from groups I-III. Numbers of grains correspond to the numbers in Table $1 \&$ Table 3. The analytical craters (white circles) with numbers and the measured $207 \mathrm{~Pb} / 206$ $\mathrm{Pb}$ ages are indicated.

Table 2: Analytical U-Pb SIMS SHRIMP data on zircons from websterite UR 17/2-3.

\begin{tabular}{|c|c|c|c|c|c|c|c|c|c|c|c|c|c|c|}
\hline Crater & $\begin{array}{c}\% \\
{ }^{206} \mathrm{Pbc}\end{array}$ & U ppm & Th ppm & ${ }^{232} \mathrm{Th}$ & $\begin{array}{c}{ }^{206} \mathrm{~Pb}^{*} \\
\text { ppm }\end{array}$ & $\begin{array}{c}\text { Age, } \\
{ }^{206} \mathrm{~Pb}^{*} /{ }^{238} \mathrm{U}\end{array}$ & Ma & $\begin{array}{c}\text { Age, } \\
{ }^{207} \mathrm{~Pb}^{*} /{ }^{206} \mathrm{~Pb}^{*}\end{array}$ & Ma & ${ }^{207} \mathrm{~Pb}^{* / 235} \mathrm{U}$ & $\pm \%$ & $\begin{array}{l}{ }^{206} \mathrm{~Pb}^{*} / \\
{ }^{238} \mathrm{U}\end{array}$ & $\pm \%$ & Rho \\
\hline 1.1 & 0.27 & 138 & 101 & 0.76 & 33.3 & 1589 & \pm 11 & 1731 & \pm 36 & 4.08 & 2.1 & 0.2795 & 0.8 & 0.379 \\
\hline 2.1 & 0.01 & 92 & 110 & 1.24 & 39.8 & 2638 & \pm 25 & 2771 & \pm 20 & 13.49 & 1.7 & 0.5057 & 1.1 & 0.677 \\
\hline 3.1 & 0.14 & 445 & 503 & 1.17 & 112 & 1652 & \pm 11 & 2012 & \pm 18 & 4.99 & 1.2 & 0.292 & 0.7 & 0.586 \\
\hline 4.1 & 0.01 & 6675 & 428 & 0.07 & 20.5 & 1972 & \pm 24 & 2265 & \pm 19 & 7.06 & 1.8 & 0.3579 & 1.4 & 0.786 \\
\hline 5.1 & 0.14 & 131 & 126 & 0.99 & 45.9 & 2206 & \pm 17 & 2493 & \pm 19 & 9.2 & 1.4 & 0.408 & 0.9 & 0.63 \\
\hline 6.1 & 0.08 & 118 & 90 & 0.78 & 57.9 & 2909 & \pm 20 & 2833 & \pm 13 & 15.79 & 1.2 & 0.5702 & 0.9 & 0.721 \\
\hline 6.2 & 0.01 & 103 & 48 & 0.46 & 50.3 & 2766 & \pm 20 & 2779 & \pm 15 & 14.35 & 1.3 & 0.5359 & 0.9 & 0.709 \\
\hline
\end{tabular}




\begin{tabular}{|c|c|c|c|c|c|c|c|c|c|c|c|c|c|c|}
\hline 7.1 & 0.15 & 73 & 96 & 1.35 & 32.1 & 2655 & \pm 25 & 2835 & \pm 18 & 14.13 & 1.6 & 0.5095 & 1.1 & 0.712 \\
\hline 8.1 & 0.07 & 134 & 82 & 0.63 & 63.8 & 2835 & \pm 18 & 2798 & \pm 13 & 14.96 & 1.1 & 0.5523 & 0.8 & 0.707 \\
\hline 8.2 & 0.01 & 375 & 408 & 1.13 & 17.3 & 2774 & \pm 15 & 2785 & \pm 7 & 14.46 & 0.8 & 0.5379 & 0.7 & 0.835 \\
\hline 9.1 & 1 & 54 & 48 & 0.92 & 26.9 & 2908 & \pm 41 & 2766 & \pm 35 & 15.15 & 2.8 & 0.57 & 1.8 & 0.634 \\
\hline 9.2 & 0.06 & 465 & 254 & 0.57 & 201 & 2622 & \pm 29 & 2715 & \pm 6 & 12.93 & 1.4 & 0.5018 & 1.3 & 0.971 \\
\hline 10.1 & 0.27 & 111 & 52 & 0.48 & 51.1 & 2754 & \pm 35 & 2738 & \pm 13 & 13.93 & 1.7 & 0.533 & 1.6 & 0.897 \\
\hline 10.2 & 0.08 & 311 & 256 & 0.85 & 150 & 2868 & \pm 32 & 2835 & \pm 22 & 15.53 & 1.9 & 0.5603 & 1.4 & 0.711 \\
\hline
\end{tabular}

The majority of zircon I and II shows a narrow range of REE the moderate Th/U ratio (average 0.73) are typical for magmatic concentrations and a typical magmatic chondrite-normalised REE rocks (Table 3). Zircon grains 3.1, 5.1, 9.1 reveal a more flatter profile (La to Lu slope, Eu and Ce anomalies; Figure 3; Table 3. Small REE pattern (average $\mathrm{Lu}_{\mathrm{n}} / \mathrm{La}_{\mathrm{n}}=306, \mathrm{Sm}_{\mathrm{n}} / \mathrm{La}_{\mathrm{n}}=3$; Figure 3). These negative Eu- and high positive Ce- anomalies, high amounts of $\mathrm{Y}$ and $\quad$ grains contain significant amounts of $\mathrm{Ca}, \mathrm{Ti}, \mathrm{Li}, \mathrm{Sr}, \mathrm{Nb}, \mathrm{Ba}$ caused by Hf up to 11000 ppm suggest the magmatic origin of zircon $[10,11]$. secondary alteration produced by $\mathrm{H}_{2} \mathrm{O}$-rich fluid [12].

Zircons I and II having the moderate Th and U concentrations and

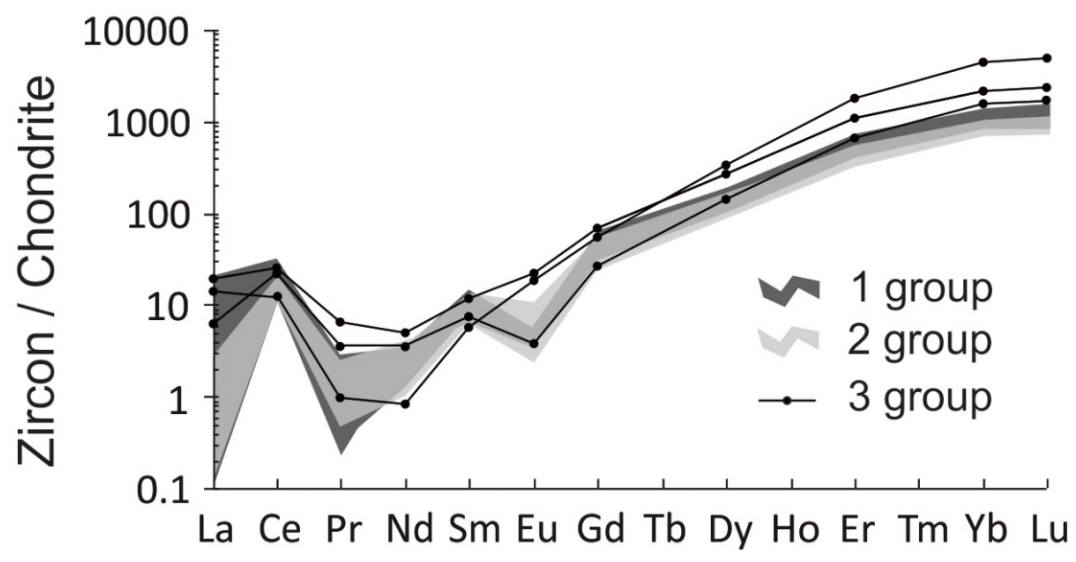

Figure 3: Chondrite-normalized REE patterns for zircon from the websterite (sample UR 17/2-3).

Table 3: Trace element and REE concentrations in zircon from websterite (UR17/2-3).

\begin{tabular}{|c|c|c|c|c|c|c|c|c|c|c|c|c|c|c|c|c|c|}
\hline $\begin{array}{l}\text { Zircon } \\
\text { Group } \\
\text { Point }\end{array}$ & $\begin{array}{c}\text { I } \\
1.1\end{array}$ & $\begin{array}{c}\text { I } \\
6.1\end{array}$ & $\begin{array}{c}\text { I } \\
6.2\end{array}$ & $\begin{array}{c}\text { I } \\
7.1\end{array}$ & $\begin{array}{c}\text { I } \\
8.1\end{array}$ & $\begin{array}{c}\text { I } \\
8.2\end{array}$ & $\begin{array}{c}\text { I } \\
5.1\end{array}$ & $\begin{array}{l}\text { I/II } \\
3.1\end{array}$ & $\begin{array}{l}\text { I/II } \\
2.1\end{array}$ & $\begin{array}{c}\text { II } \\
10.1\end{array}$ & $\begin{array}{c}\text { II } \\
10.2\end{array}$ & $\begin{array}{c}\text { II } \\
9.1\end{array}$ & $\begin{array}{c}\text { II } \\
9.2\end{array}$ & $\begin{array}{c}\text { II } \\
\text { R12 }\end{array}$ & $\begin{array}{l}\text { III } \\
4.1\end{array}$ & $\begin{array}{c}\text { III } \\
\text { R15 }\end{array}$ & $\begin{array}{c}\text { III } \\
\text { R14 }\end{array}$ \\
\hline $\mathrm{La}$ & 0.04 & 0.11 & 0.05 & 0.03 & 0.05 & 0.06 & 0.51 & 6.46 & 0.04 & 0.04 & 0.39 & 0.8 & 0.39 & 0.88 & 1.95 & 6.05 & 4.34 \\
\hline $\mathrm{Ce}$ & 12.1 & 9.43 & 8.85 & 11.73 & 13.6 & 22.1 & 14.2 & 26.27 & 11.43 & 10.59 & 18.52 & 15.3 & 18.52 & 8.73 & 17.58 & 20.92 & 9.43 \\
\hline $\operatorname{Pr}$ & 0.05 & 0.05 & 0.03 & 0.04 & 0.07 & 0.08 & 0.25 & 0.4 & 0.07 & 0.06 & 0.17 & 0.35 & 0.173 & 0.21 & 0.5 & 0.89 & 0.13 \\
\hline $\mathrm{Nd}$ & 0.86 & 0.69 & 1.91 & 0.78 & 0.97 & 1.17 & 1.63 & 2.06 & 0.85 & 0.6 & 1.23 & 2.25 & 1.231 & 0.97 & 2.08 & 2.96 & 0.52 \\
\hline $\mathrm{Sm}$ & 1.83 & 1.6 & 1.26 & 1.93 & 1.92 & 2.84 & 1.91 & 2.81 & 1.82 & 1.19 & 2.36 & 2.62 & 2.364 & 0.72 & 1.42 & 2.29 & 1.11 \\
\hline $\mathrm{Eu}$ & 0.42 & 0.31 & 0.25 & 0.38 & 0.36 & 0.37 & 0.32 & 0.42 & 0.38 & 0.17 & 0.35 & 0.77 & 0.353 & 0.35 & 0.27 & 1.56 & 1.33 \\
\hline $\mathrm{Gd}$ & 12.43 & 9.57 & 8.18 & 13.73 & 14.39 & 16.39 & 9.85 & 13.92 & 11.57 & 6.45 & 13.83 & 12.4 & 13.83 & 3.81 & 6.93 & 17.34 & 14.18 \\
\hline Dy & 56.93 & 47.11 & 38.35 & 55.53 & 60.89 & 67.74 & 47.6 & 55.75 & 48.7 & 32.58 & 60.73 & 57 & 60.73 & 23.55 & 52.26 & 98.18 & 122 \\
\hline Er & 142 & 107 & 88.7 & 117 & 144 & 151 & 94.91 & 109 & 108 & 71.24 & 124 & 109 & 124 & 63.68 & 134 & 227 & 384 \\
\hline $\mathrm{Yb}$ & 281 & 213 & 175 & 208 & 255 & 246 & 169 & 196 & 182 & 136 & 220 & 205 & 220 & 146 & 317 & 440 & 927 \\
\hline $\mathrm{Lu}$ & 49.67 & 37.05 & 29.99 & 34.84 & 41.38 & 40.26 & 26.73 & 29.74 & 31.5 & 22.64 & 33.76 & 31.2 & 33.76 & 26.3 & 55 & 74.2 & 155 \\
\hline
\end{tabular}




\begin{tabular}{|c|c|c|c|c|c|c|c|c|c|c|c|c|c|c|c|c|c|}
\hline $\mathrm{Li}$ & 2.63 & 7.55 & 4.25 & 0.19 & 4.84 & 14.08 & 10.53 & 12.28 & 2.59 & 4.83 & 23.25 & 6.6 & 23.25 & 38 & 35 & 34 & 47 \\
\hline P & 202 & 180 & 120 & 182 & 206 & 210 & 153 & 181 & 160 & 181 & 146 & 141 & 146 & 89 & 282 & 447 & 730 \\
\hline $\mathrm{Ca}$ & 0.65 & 2.83 & 1.48 & 2.04 & 2.58 & 1.46 & 64 & 269 & 9.13 & 17 & 253 & 1328 & 253 & 60 & 391 & 190 & 61 \\
\hline $\mathrm{Ti}$ & 1.54 & 6.07 & 1.96 & 3.19 & 2.18 & 2.49 & 4.7 & 13.3 & 3.01 & 6 & 7.6 & 56 & 7.6 & 6 & 18 & 18 & 10 \\
\hline $\mathrm{Sr}$ & 0.35 & 0.08 & nd & 0.23 & 0.24 & 0.27 & 1.55 & 2.46 & 0.29 & 0.73 & 4.91 & 11.4 & 4.91 & 1.66 & 5.31 & 3.07 & 3.27 \\
\hline Y & 747 & 640 & 491 & 675 & 769 & 838 & 627 & 748 & 592 & 430 & 805 & 728 & 805 & 363 & 763 & 1325 & 2039 \\
\hline $\mathrm{Nb}$ & 14.2 & 12.03 & 0.93 & 4.99 & 7.14 & 12.08 & 69.4 & 68.6 & 14.4 & 56.8 & 69.8 & 51 & 85.5 & 56.7 & 53.5 & 108 & 61.2 \\
\hline $\mathrm{Ba}$ & 0.52 & 0.96 & 0.74 & 0.69 & 0.73 & 0.54 & 3 & 6 & 0.81 & 2.2 & 6 & 13.3 & 5.99 & 3.39 & 4.74 & 7.18 & 5.83 \\
\hline $\mathrm{Hf}$ & 9370 & 10068 & 10363 & 9070 & 9519 & 11444 & 7289 & 8706 & 9270 & 8394 & 10039 & 8643 & 10039 & 9102 & 10248 & 8819 & 12435 \\
\hline $\mathrm{U}$ & 138 & 118 & 103 & 73 & 134 & 375 & 131 & 445 & 92 & 111 & 449 & 134 & 923 & 1081 & 6675 & 1473 & 2230 \\
\hline Th & 101 & 90 & 48 & 96 & 82 & 408 & 126 & 503 & 110 & 52 & 290 & 63 & 261 & 57 & 428 & 319 & 235 \\
\hline $\mathrm{Th} / \mathrm{U}$ & 0.73 & 0.76 & 0.47 & 1.32 & 0.61 & 1.09 & 0.96 & 1.13 & 1.2 & 0.47 & 0.65 & 0.47 & 0.28 & 0.05 & 0.07 & 0.22 & 0.11 \\
\hline $\mathrm{Eu} / \mathrm{Eu}^{*}$ & 0.27 & 0.24 & 0.23 & 0.23 & 0.21 & 0.17 & 0.2 & 0.2 & 0.25 & 0.19 & 0.19 & 0.41 & 0.49 & 0.7 & 0.26 & 0.76 & 1 \\
\hline $\mathrm{Ce} / \mathrm{Ce}^{*}$ & 63 & 32 & 53 & 78 & 56 & 77 & 10 & 4 & 51 & 52 & 17 & 7 & 17 & 5 & 4 & 2 & 3 \\
\hline ELREE & 13 & 10 & 11 & 13 & 15 & 23 & 17 & 35 & 12 & 11 & 20 & 19 & 28 & 11 & 22 & 31 & 14 \\
\hline$\Sigma$ HREE & 542 & 413 & 340 & 429 & 516 & 521 & 347 & 404 & 381 & 269 & 452 & 415 & 295 & 263 & 565 & 850 & 1603 \\
\hline $\begin{array}{c}\text { LuN/ } \\
\text { LaN }\end{array}$ & 12046 & 3124 & 5299 & 10739 & 7455 & 6759 & 504 & 44 & 6874 & 5402 & 829 & 376 & 563 & 298 & 272 & 118 & 343 \\
\hline $\begin{array}{c}\text { SmN/ } \\
\text { LaN }\end{array}$ & 74 & 22 & 37 & 99 & 58 & 79 & 6 & 1 & 66 & 47 & 10 & 5 & 11 & 1 & 1 & 1 & 0.4 \\
\hline $\mathrm{Lu} / \mathrm{Hf}$ & 0.004 & 0.002 & 0.002 & 0.003 & 0.004 & 0.003 & 0.003 & 0.0035 & 0.004 & 0.002 & 0.004 & 0 & 0.002 & $0.003^{*}$ & 0.009 & $0.008^{*}$ & $0.013 *$ \\
\hline $\mathrm{T}(\mathrm{Ti}), \mathrm{C}^{\circ}$ & 601 & 701 & 617 & 651 & 624 & 634 & 680 & 769 & 647 & 705 & 719 & 921 & 804 & 702 & 800 & 798 & 745 \\
\hline
\end{tabular}

Trace element concentrations were analyzed by ion microprobe zircon grains R12, R14 and R15 were used elemental data (this Cameca IMS-4f (Jaroslavl branch of PhT1 RAS, Russia). Lu/Hf are Table).

the isotopic data (see Table 5), *- for the calculation of Lu/Hf in

Table 4: Composition of zircon grains websterite (UR-17/2-3).

\begin{tabular}{|c|c|c|c|c|c|c|c|c|c|c|c|}
\hline Zircon Group & Grain & Point & $\mathrm{SiO}_{2}$ & $\mathrm{ZrO}_{2}$ & $\mathrm{HfO}_{2}$ & $\mathrm{Zr} / \mathrm{Hf}$ & $\mathrm{FeO}$ & Mno & MgO & $\mathrm{CaO}$ & $\mathrm{Na}_{2} \mathrm{O}$ \\
\hline small & 1559 & 66 & 33.38 & 65.01 & 1.62 & 35 & nd & nd & nd & nd & nd \\
\hline small & 1559 & 67 & 33.7 & 64.99 & 1.3 & 43.7 & nd & nd & nd & nd & nd \\
\hline small & 1559 & 68 & 33.18 & 66.25 & 1.57 & 36.1 & nd & nd & nd & nd & nd \\
\hline small & 1559 & 69 & 33.61 & 64.74 & 1.65 & 34.3 & nd & nd & nd & nd & nd \\
\hline small & 1559 & 70 & 33.54 & 65.62 & 0.84 & 68.2 & nd & nd & nd & nd & nd \\
\hline small & 1559 & 71 & 33.16 & 65.07 & 1.77 & 32.1 & nd & nd & nd & nd & nd \\
\hline small & 1559 & 72 & 32.69 & 65.66 & 1.65 & 34.7 & nd & nd & nd & nd & nd \\
\hline small & 1559 & 73 & 34.12 & 64.61 & 1.27 & 44.4 & nd & nd & nd & nd & nd \\
\hline I & 7.1 & 39 & 33.1 & 65.5 & 1.29 & 41.1 & nd & nd & nd & nd & nd \\
\hline I & 7.1 & 40 & 33.3 & 65.5 & 1.29 & 46.3 & nd & nd & nd & nd & nd \\
\hline I & 6.1 & 33 & 33.4 & 64.6 & 1.98 & 38.3 & nd & nd & nd & nd & nd \\
\hline I & 6.2 & 34 & 33.1 & 65.4 & 1.49 & 28.6 & nd & nd & nd & nd & nd \\
\hline I & 8.1 & 52 & 33.6 & 65.3 & 1.12 & 51 & nd & nd & nd & nd & nd \\
\hline I & 8.2 & 53 & 33.4 & 65 & 1.68 & 33.8 & nd & nd & nd & nd & nd \\
\hline I & 8.2 & 54 & 33.4 & 65 & 1.61 & 35.2 & nd & nd & nd & nd & nd \\
\hline $\mathrm{I} / \mathrm{II}$ & 2.1 & 1 & 33.6 & 64.2 & 2.27 & 25.1 & nd & nd & nd & nd & nd \\
\hline $\mathrm{I} / \mathrm{II}$ & 2.1 & 2 & 33.5 & 66.11 & 1.43 & 38.1 & nd & nd & nd & nd & nd \\
\hline $\mathrm{I} / \mathrm{II}$ & 2.1 & 3 & 32.7 & 65.9 & 1.36 & 42.3 & nd & nd & nd & nd & nd \\
\hline II & 10.1 & 19 & 33.5 & 64.9 & 1.6 & 35.4 & nd & nd & nd & nd & nd \\
\hline
\end{tabular}




\begin{tabular}{|c|c|c|c|c|c|c|c|c|c|c|c|}
\hline II & 10.2 & 20 & 33.5 & 64.8 & 1.7 & 32.9 & nd & nd & nd & nd & nd \\
\hline II & 9.1 & 21 & 33.6 & 65.7 & 0.74 & 77.5 & nd & nd & nd & nd & nd \\
\hline II & 9.2 & 22 & 33.4 & 65 & 0.62 & 35 & nd & nd & nd & nd & nd \\
\hline III & 4.1 & 23 & 33 & 66 & 0.99 & 58 & nd & nd & nd & nd & nd \\
\hline III & 4.1 & 24 & 34 & 64 & 1.97 & 28 & nd & nd & nd & nd & nd \\
\hline III & 4.1 & 25 & 33 & 66 & 1.34 & 43 & nd & nd & nd & nd & nd \\
\hline «W-II» & R12 & 48 & 33.5 & 65.1 & 1.43 & 39.7 & nd & nd & nd & nd & nd \\
\hline «W-III» & 4.1 & 26 & 31 & 61 & 1.8 & 30 & 1.68 & 1 & 0.53 & 1.5 & 0.69 \\
\hline «W-III» & 4.1 & 27 & 32 & 62 & 1.9 & 28 & 1.08 & 0.86 & 0.31 & 1.53 & 0.73 \\
\hline «W-III» & R14 & 55 & 33.9 & 65 & 1.12 & 50.7 & nd & nd & nd & nd & nd \\
\hline «W-III» & R15 & 56 & 32.9 & 64.5 & 2.58 & 21.8 & nd & nd & nd & nd & nd \\
\hline
\end{tabular}

"w" - zircons with wormy convolute texture of II or III group, nd - not detectable. The analytical method used is as in the Table 1.

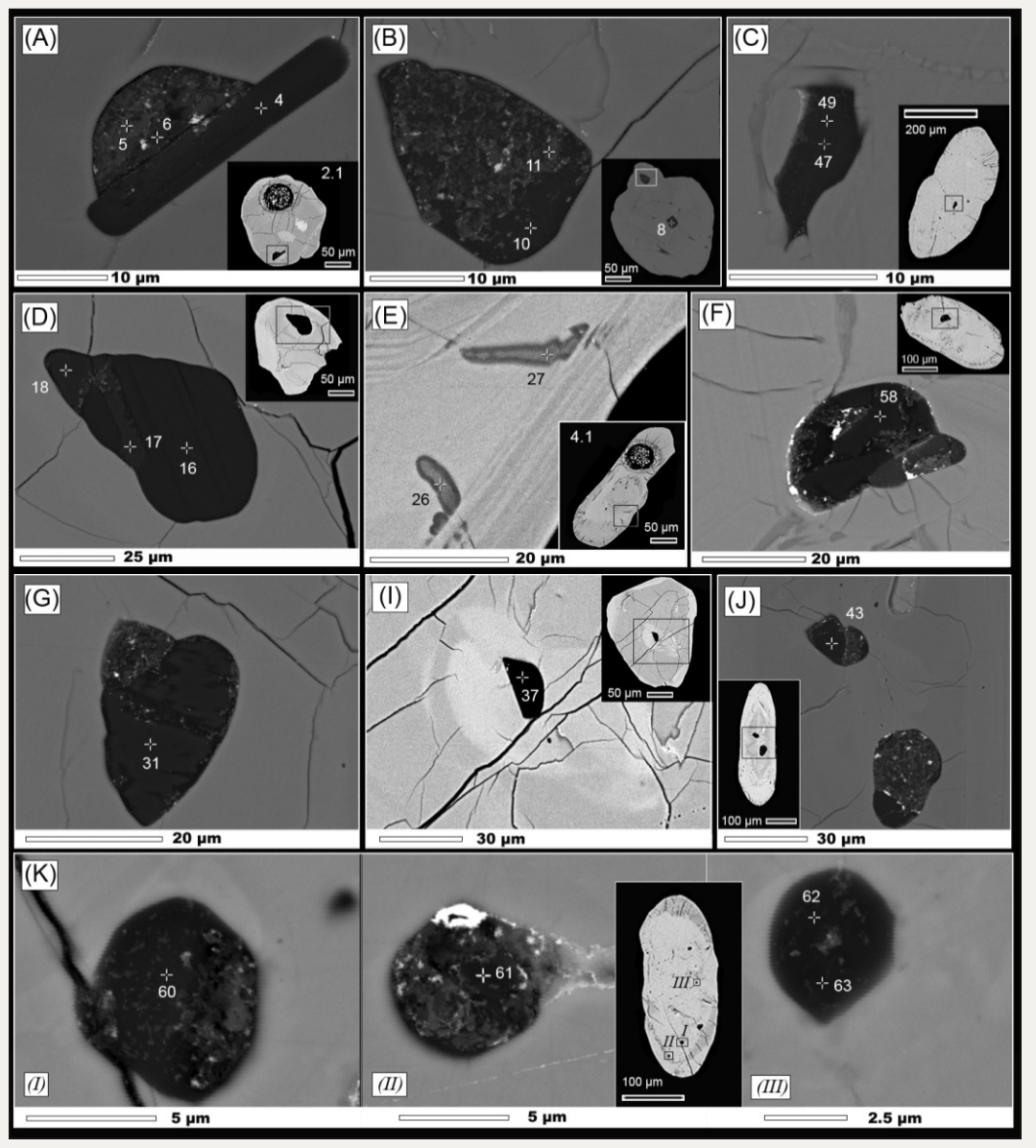

Figure 4: Mineral inclusions in zircon. Numbers within the inclusions correspond to those in Table $1 \&$ Table 4 . The hydrothermal changes ("wormy convolute textures") are seen in plot "E" $(026,027)$ and "J" (059). The composition of zircon: points $9,26,27$, 35, 36, 48, 59 are in Table 4.

Orthopyroxene, amphibole and phlogopite inclusions in both zircon groups are similar in composition to those from the host websterite (Table 1). These petrographic and geochemical data suggest that zircon growth was essentially synchronous with orthopyroxene and phlogopite crystallization in the websterite matrix. Zircon III is represented by elongated grains composed of cores visible in BSE filled by numerous mineral inclusions, and rims with radial fractures. These grains are strongly altered as indicated by dapple texture and wormy convolute texture seen in BSE images (Figure 4E). Zircon III strongly contrasts with zircon I and II in $\mathrm{Lu}, \mathrm{Li}, \mathrm{U}$ concentrations, and $\mathrm{Lu} / \mathrm{Hf}, \mathrm{Th} / \mathrm{U}$ ratios (Table 3). Zircon III is characterized by a more flat REE distribution. Chemical composition of zircon III corresponds to that of zircon from ordinary mafic rocks [13]. But low Th/U ratio indicates the metamorphic 
alteration of zircon III [11]. High abundances of $\mathrm{Ba}, \mathrm{P}, \mathrm{Ca}, \mathrm{Nb}$, low $\mathrm{Lu}_{\mathrm{n}} / \mathrm{La}_{\mathrm{n}}$ (average $=258$ ), and Eu-, Ce-anomalies make them similar to the altered grains of zircons I and II. So, zircon III is magmatic in origin and was strongly altered by fluids. Distinguished zircon groups are not detectable in $\mathrm{Zr} / \mathrm{Hf}$ ratio. Although some variations exist the average $\mathrm{Zr} / \mathrm{Hf}$ value is about 40 (Table 4).

The last hydrothermal process recovered in zircon III formed wormy convolute texture of zircon and altered mineral inclusions (Figure 4E). The convoluted domains contain 1.5-1.6wt.\% of $\mathrm{Hf}$ and significant amounts of non-formula elements such as $\mathrm{Fe}, \mathrm{Mn}, \mathrm{Ca}, \mathrm{Mg}$ and $\mathrm{Na}$ (Table 4). Mineral inclusions are oval or rounded in shape.
Their fine-grained matrix composed of intensively altered Opx and Cpx, Phl, minor Ap and Carb (Figure 4); (Table 1). Fractures crosscutting all internal textural elements of zircons are filled by very fine opaque minerals.

\section{Zircon U-Pb SIMS SHRIMP Age}

14 isotope in-situ analyses for the used technique see, [3] were performed for 10 zircon grains separated from the websterite (UR17/2-3, Figure 1C; Table 2). A regression line through the ten data points defines upper intercept at age of $2814 \pm 51$ Ma and lower intercept at $1474 \pm 140$ Ma (Figure 5). Value 2814 Ma is not entirely acceptable because

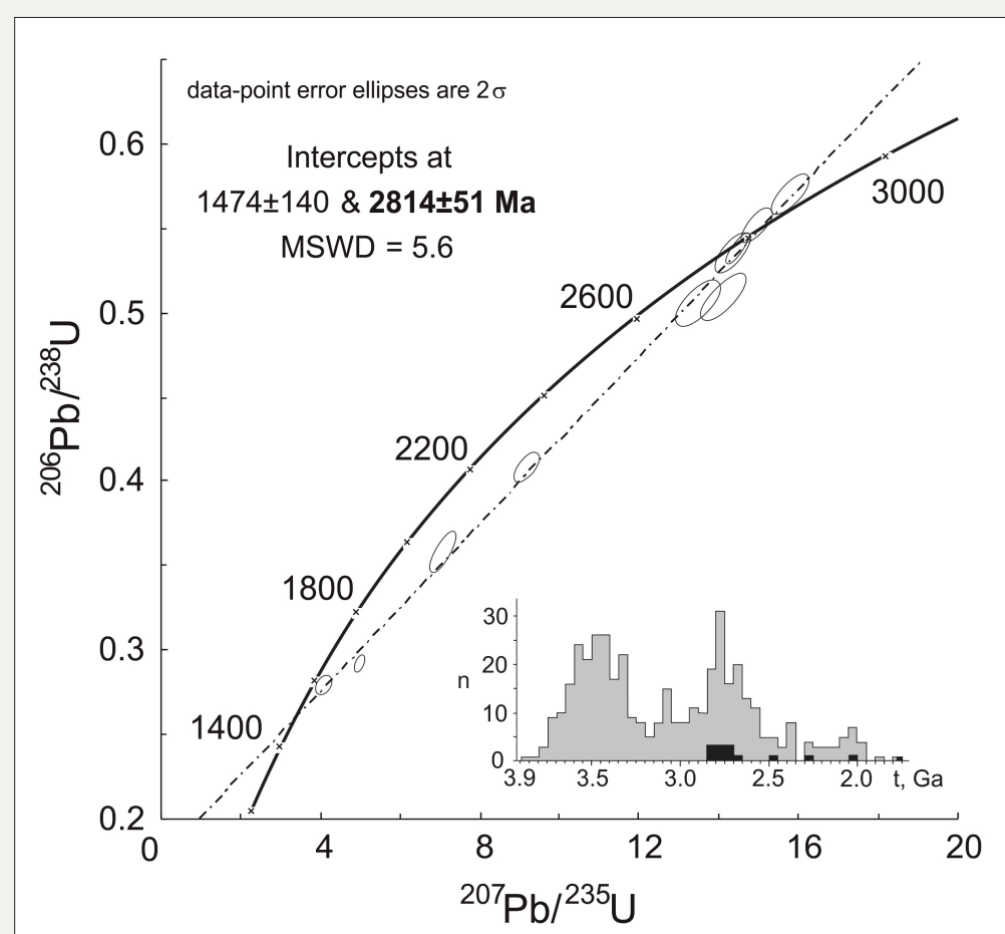

Figure 5: U-Pb concordia diagram for zircon from the websterite (sample UR 17/2-3). Inset shows U-Pb SIMS isotope ages histogram for the Bug Granulite Complex, $n=420$; the UR17/2-3 data are shown in black. The age values of the grains with discordance more $10 \%$ are excluded [date uses from, 3, 5-7,9].

1. Some points do not lie close to the regression line.

2. The lower intercept age is difficult to interpret.

Despite the existences of the experimental points near the lower intercept of the Discordia, it seems that the age of $1474 \pm 140$ Ma has no geological meaning because all known U-Pb zircon ages vary from 3.75 to $1.9 \mathrm{Ga}$ (Figure 5). Furthermore, a Rb-Sr isochron (calculated for phlogopites, ultramafic samples UR17/2-2 and UR135) give the age of $1700 \pm 19 \mathrm{Ma}$ (unpublished our data). K-Ar ages from the studied Bug region show the peak values for biotite of $1775 \mathrm{Ma}$ (35\% of all ages), and a range of 1975-2125Ma for amphibole (63\% of all ages) [14]. These data represent cooling ages of the Bug granulite complex during its exhumation. Possibly, the age of $1475 \pm 140$ Ma may identify local hydrothermal alteration.

$207 \mathrm{~Pb} / 206 \mathrm{~Pb}$ ages determined for six subconcordant grains (discordancy less than $7 \%$ ) of zircon I are within the range of 2.83-2.77Ga. Two subconcordant grains (4 points) of zircon II yield $207 \mathrm{~Pb} / 206 \mathrm{~Pb}$ ages of 2.77 to $2.72 \mathrm{Ga}$ (Table 2). So, the age of magmatic crystallization of zircon I are assumed to be of 2.83-2.77Ga. Probably, the age of about 2.77-2.72Ga reflects a metamorphic process which changed composition of zircon and mineral inclusions.

\section{Lu-Hf Isotopic System in Zircon}

Hafnium isotope analyses for the used technique see, [3] was performed for 10 zircon grains from the websterite which were dated by the U-Pb method. These yielded similar initial $176 \mathrm{Hf} / 177 \mathrm{Hf}$ ratios (0.280690-0.280749) and identical values of $176 \mathrm{Lu} / 177 \mathrm{Hf}$ and $176 \mathrm{Yb} / 177 \mathrm{Hf}$ except the grain 4.1 (zircon III) with very high U (6675 ppm; Table 2). In case of the high Lu/Hf ratio LA-MS ICP technique used here does not permit a correct evaluation of the $176 \mathrm{Hf} / 177 \mathrm{Hf}$ isotopic ratio. Hafnium isotopic data for the grain 4.1 are not robus and were excluded from interpretation. Meanwhile, not only the grain 4.1 (zircon III) has higher Lu/Hf in comparison 
with zircon I and II. As seen in Table 3, other grains of zircon III have also high Lu amounts and high Lu/Hf ratio. It suggests that studied websterite crystallized from not completely homogeneous melt.

The position of data-points of zircon grains on the diagram $\varepsilon H f(t)-\varepsilon N d(t)$ within "terrestrial array" indicates their crystallization from the melt (Figure 6A) [15]. If we use Nd isotopic data on the lherzolite (Table 6), the data-points shifted to the area of xenogenic zircons contained inherited non-radiogenic hafnium. These data indicate the zircon crystallization from a hybrid melt.

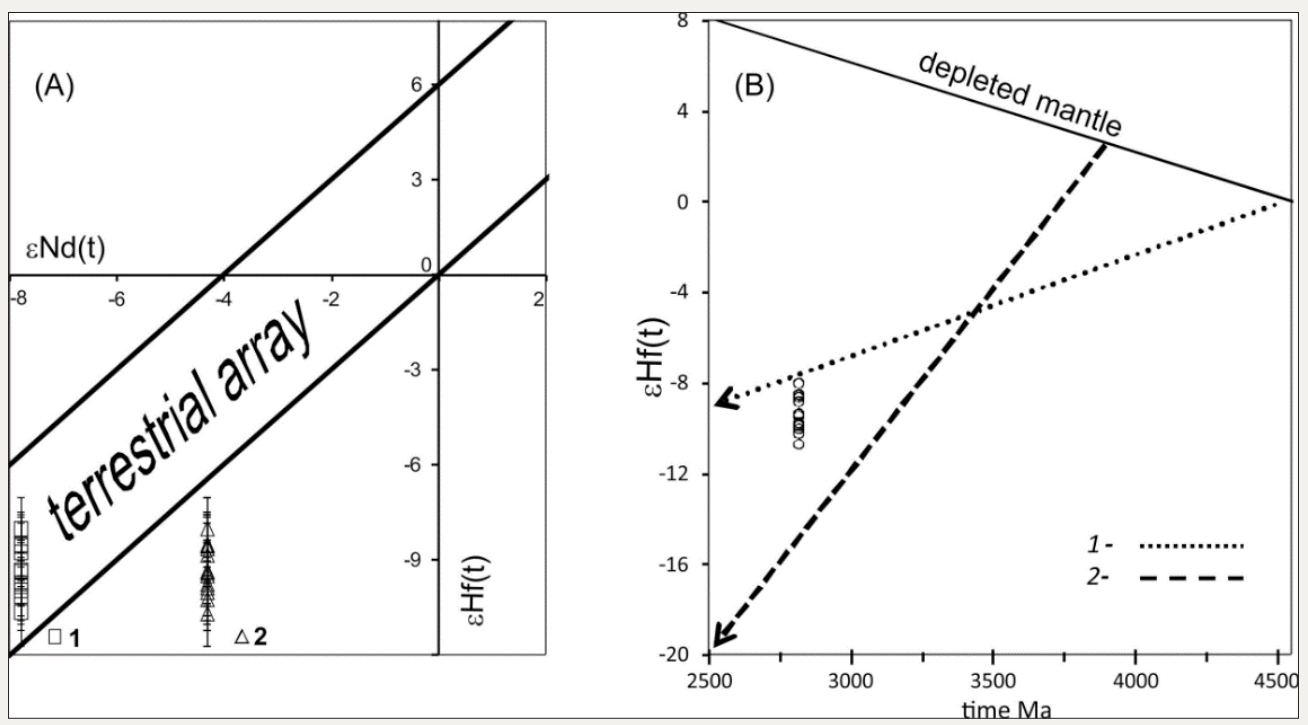

Figure 6: Hf and Hf-Nd isotope plots for zircon from websterite (sample UR17/2-3).

Figure 6A: Isotopic Hf-Nd systematic. Solid lines define area for magmatic zircons [15]. The location of zircon points (1) for websterite with $\varepsilon N d(\mathrm{t})$ values (Table 6) and (2) those assuming crystallization from the melt with Nd-isotopic characteristics of lherzolite UR $17 / 2-2$.

Figure 6B: Hf evolution diagram. Evolution lines: depleted mantle $-{ }^{176} \mathrm{Lu} /{ }^{177} \mathrm{Hf}=0.03841-$ ultramafic rock $-{ }^{176} \mathrm{Lu} /{ }^{177} \mathrm{Hf}=0.028$, [17] 2 - gneisses $-{ }^{176} \mathrm{Lu} /{ }^{177} \mathrm{Hf}=0.009$ [16].

Table 5: Hf isotopic compositions of zircon separated from websterite (UR-17/2-3).

\begin{tabular}{|c|c|c|c|c|c|c|}
\hline Grain & ${ }^{176} \mathbf{Y b} /{ }^{177} \mathbf{H f}$ & $\mathbf{\pm 1 \sigma}$ & ${ }^{176} \mathbf{L u} /{ }^{177} \mathbf{H f}$ & $\pm \mathbf{1 \sigma}$ & ${ }^{176} \mathbf{H f} /{ }^{177} \mathbf{H f}$ & $\mathbf{\pm 1 \sigma}$ \\
\hline 1.1 & 0.019966 & 0.00079 & 0.000579 & 0.000006 & 0.280779 & 0.000021 \\
\hline 2.1 & 0.021201 & 0.000614 & 0.000603 & 0.000002 & 0.280763 & 0.000021 \\
\hline 3.1 & 0.017957 & 0.00077 & 0.0005 & 0.000003 & 0.280722 & 0.000021 \\
\hline 4.1 & 0.037931 & 0.000545 & 0.001243 & 0.000012 & 0.280769 & 0.000011 \\
\hline 5.1 & 0.014545 & 0.000317 & 0.000416 & 0.000001 & 0.280747 & 0.000018 \\
\hline 6.1 & 0.010717 & 0.000896 & 0.000318 & 0.000009 & 0.280749 & 0.000016 \\
\hline 6.2 & 0.010415 & 0.000297 & 0.000307 & 0.000001 & 0.280726 & 0.000021 \\
\hline 7.1 & 0.014475 & 0.000179 & 0.000411 & 0.000003 & 0.280707 & 0.000023 \\
\hline 8.1 & 0.018283 & 0.000419 & 0.000535 & 0.000001 & 0.28072 & 0.000015 \\
\hline 8.2 & 0.014616 & 0.000331 & 0.00043 & 0.000001 & 0.280721 & 0.000019 \\
\hline 9.1 & 0.01451 & 0.000541 & 0.000416 & 0.000005 & 0.280756 & 0.000018 \\
\hline 9.2 & 0.011756 & 0.00014 & 0.000339 & 0.000007 & 0.28069 & 0.000016 \\
\hline 10.1 & 0.009671 & 0.000414 & 0.000291 & 0.000002 & 0.280725 & 0.000019 \\
\hline 10.2 & 0.020126 & 0.000399 & 0.00056 & 0.000007 & 0.280737 & 0.000016 \\
\hline
\end{tabular}

The Lu-Hf isotope measurements were performed using a 193nm Ar-F COMPex-102 laser, a DUV-193 ablation system (Lambda Physic) and a Neptune MC-ICP-MS (Thermo Fisher) at the CIR. The
Faraday cups' configuration allowed the simultaneous registration of $172 \mathrm{Yb}, 174 \mathrm{Yb}, 175 \mathrm{Lu}, 176(\mathrm{Hf}+\mathrm{Lu}+\mathrm{Yb}), 177 \mathrm{Hf}, 178 \mathrm{Hf}$ and $179 \mathrm{Hf}$. 
Table 6: Sm-Nd isotopic data for the rocks of the peridotite lens.

\begin{tabular}{|c|c|c|c|c|c|c|}
\hline Rock Type & Sample & Sm & Nd & ${ }^{147 / 144} \mathrm{Nd}$ & ${ }^{143 / 144} \mathrm{Nd}$ & $\pm 2 \sigma$ \\
\hline Lherzolite & UR $17 / 2$ & 1.154 & 4.223 & 0.1652 & 0.511833 & 19 \\
\hline Websterite & UR 17/2-3 & 1.179 & 4.324 & 0.1649 & 0.51165 & 15 \\
\hline
\end{tabular}

Calculated $\varepsilon H f$ (2.8Ga) varies from -8.0 to -10.7 (average value -9.0) (Figure 6B). Negative $\varepsilon \mathrm{Hf}(\mathrm{t})$ value shows that a pre-existing crust was assimilated by peridotite melt (Table 5).

Thus, the difference between the $\mathrm{Nd}$ isotope composition of lherzolite and websterite is consistent with a model of contamination of original lherzolite melt by the older rock. If the minimal value $\varepsilon \mathrm{Hf}(2.8 \mathrm{Ga}$ ) corresponds to the maximal contribution of a gneiss contaminant with $\varepsilon \mathrm{Hf}(\mathrm{t})$ of 0.007-0.009 [16,17], a two-stage Hf model age of ca. 3.65Ga may be calculated for a contaminant.

\section{Discussion and Main Conclusion}

A synthesis of combined Lu-Hf and U-Pb isotopic zircon data indicates hybrid origin of melt from which zircon crystallized. Practically all zircon grains show signs of alteration which increases from zircon I to zircon III. This alteration was accompanied by a local redistribution of $\mathrm{Zr}$ and $\mathrm{Hf}$ and indicates a significant fluid reworking that led to redistribution of these elements in zircons II and III. In general, all zircon grains maintain near chondritic $\mathrm{Zr} / \mathrm{Hf}$ ratios. The last process during which the wormy convolute texture was formed caused a strong decrease in $\mathrm{Zr} / \mathrm{Hf}$ and was probably synchronous with the alteration of pyroxene inclusions in zircon and with the origin of carbonate in zircon and in the rock matrix.

The mantle-derived lherzolite melt entrained the older crust. The marginal position of the websterite (Figure 1C) suggests the host orthogneiss as a contaminant. It is supposed that a peridotite magma was hot enough for TTG-gneiss melting. Melt intruded into orthogneiss formed dykes and geological setting of the investigated lenses does not contradict with this proposition. The geochemical and Lu-Hf isotope data show that zircon from lherzotite lens crystallized from a hybrid websterite melt which formed as a result of assimilation of original ultramafic melt by partially molten host orthogneiss.

The similarity of the mineral inclusions in zircon and minerals in host rock indicates that the age $2814 \pm 51$ Ma corresponds to the intruding time of the lherzolite dyke. Thus, it evidences a pulse of ultramafic magmatic activity in the Dniester-Bug Province about 2.8Ga ago.

\section{Acknowledgements}

We would like to thank I. Kapitonov for his help with Lu-Hf analysis and S. Presnyakov and A. Larionov for their assistance with the SHRIMP-II analyses.

The study was carried out in the context of the IPGG RAS scientific theme 0153-2018-0004, apart from the structural observations that were performed in the context of the GI KSC RAS scientific theme 0231-2015-0004

\section{References}

1. Lesnaya IM, Plotkina TE, Stepanyuk LM, Bartnitski EN (1995) Age stages of the formation of mafiteenderbite associations of the Bug Area, Geokhim. Rudoobraz (Ukraine) 21: 56-69.

2. Stepanuik LM (1996) Origin and isotopic age of zircon from maficultramafic rocks of the Middle Bug region. Mineral J (Ukraine) 18: 10-19.

3. Lobach Zhuchenko SB, Kaulina TV, Baltybaev ShK, Balagansky VV, Egorova JuS, et al. (2016) The long (3.7-2.1Ga) and multistage evolution of the Bug Granulite-Gneiss Complex, Ukrainian Shield, based on the SIMS $\mathrm{U}-\mathrm{Pb}$ ages and geochemistry of zircons from a single sample. In: Halla J, Whitehouse MJ, Ahmad T, Bagai Z (Eds.), Crust-mantle interactions and granitoid diversification: Insights from Archaean Cratons. Geol Soc, Sp. Publications, London, 449: 175-206.

4. Scherbakov IB (2005) Petrology of the Ukrainian shield. ZUKTS Lviv, Russian.

5. Claesson S, Bibikova E, Bogdanova S, Skobelev V (2006) Archaean terranes, Palaeoproterozoic reworking, and accretion in the Ukrainian Shield, East European Craton. In: Gee DG, Stephenson RA (Eds.), European Lithosphere Dynamics, Geol Soc, Memoirs, London, 32: 645654.

6. Claesson S, Bibikova E, Shumlyanskyy L, Dhuime B, Hawkesworth CJ (2014) The oldest crust in the Ukrainian Shield - Eoarchaean U-Pb ages and Hf-Nd constraints from enderbites and metasediments. In: Roberts NMW, van Kranendonk M, Parman S, Shirey S, Clift PD (Eds.), Continent Formation Through Time, Geol Soc, Sp. Publications, London, 389: 227259.

7. Bibikova EV, Claesson S, Fedotova AA, Stepanyuk LM, Shumlyansky LV, et al. (2013) Isotope-geochronological (U-Th-Pb, Lu-Hf) study of zircons from the Archean magmatic and metasedimentary rocks of the Podolia domain, Ukrainian shield. Geochemistry International 51(2): 87-108.

8. Shumlyanskyy L, Hawkesworth C, Dhuime D, Billströmb K, Claesson S, et al. $(2015){ }^{207} \mathrm{~Pb} /{ }^{206} \mathrm{~Pb}$ ages and $\mathrm{Hf}$ isotope composition of zircons from sedimentary rocks of the Ukrainian shield: Crustal growth of the southwestern part of East European craton from Archaean to Neoproterozoic. Prec Res 260: 39-54.

9. Lobach Zhuchenko SB, Baltybaev ShK, Balagansky VV, Koreshkova MYu, Lokhov K, et al. (2017) Paleoarchean orthopyroxenites of the Bug granulite-gneiss terrane of the Ukrainian Shield. Doklady Earth Sciences 474(2): 700-105.

10. Belousova EA, Griffin WL, O Reilly SY, Fisher NJ (2002) Igneous zircon: Trace element composition as an indicator of source rock type. Contrib Mineral Petrol 143(5): 602-622.

11. Hoskin PWO, Schaltegger U (2003) The composition of zircon and igneous and metamorphic petrogenesis. In: Hanchar JM, Hoskin PWO (Eds.), Zirco, Rev Mineral Geochem 53(2): 27-62.

12. Rayner N, Stern RA, Carr SD (2005) Grain-scale variations in trace element composition of fluid-altered zircon, Acasta Gneiss Complex, northwestern Canada. Contributions to Mineralogy and Petrology 148(6): 721-734.

13. Grimes CB, John BE, Cheadle MJ, Mazdab FK, Wooden JL, et al. (2009) On the occurrence, trace element geochemistry, and crystallization history of zircon from in situ ocean lithosphere. Contributions to Mineralogy and Petrology 158: 757-783.

14. Scherbak NP, Zlobenko VG, Zhukov VG (1978) Catalogue of isotopic data of the Ukrainian Shield. Naukova dumka, Kiev, Russian. 
15. Lokhov KI, Saltykova TE, Kapitonov IN, Bogomolov ES, Sergeev SA et al. (2009) Correct interpretation of the U-Pb age by zircons on the basis of isotopic geochemistry of hafnium and neodymium (on the example of some magmatic complexes of the basement of Eastern-European platform). Region Geol Metallogeny 38: 62-72.

16. Amelin Yu, Lee DC, Halliday AN (2000) Early-middle Archaean crustal evolution deduced from Lu-Hf and U-Pb isotopic studies of single zircon grains. Geochimica et Cosmochimica Acta 64(24): 4205-4225.

17. Griffin WL, Belousova EA, Shee SR, Pearson NJ, O Reilly SY (2004) Archean crustal evolution in the northern Yilgarn Craton: U-Pb and Hfisotope evidence from detrital zircons. Prec Res 131(3-4): 231-282. (c) (i) Creative Commons Attribution 4.0

International License

For possible submissions Click Here
Submit Article

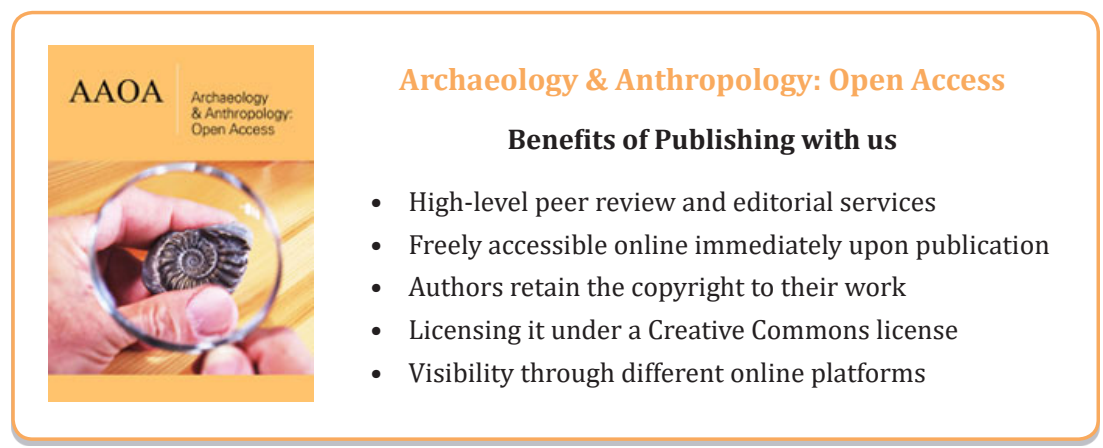

